PURBaWIDYA: Jurnal Penelitian dan Pengembangan Arkeologi p-ISSN: 2252-3758, e-ISSN: 2528-3618 Akreditasi LIPI No. 695/Akred/ P2MI-LIPI/07/2015 Vol. 7(1), Juni 2018, pp $71-88$ DOI: https://doi.org/10.24164/pw.v7i1.257

\title{
PERDAGANGAN DI PERTEMUAN SUNGAI KAPUAS DAN TAYAN, SANGGAU, KALIMANTAN BARAT, ABAD KE-19
}

\section{Trading in the Junction of Kapuas and Tayan River, Sanggau, West Kalimantan in the $19^{\text {th }}$ Century}

\author{
Sarjiyanto $^{1}$, Libra Hari Inagurasi ${ }^{2}$ \\ ${ }^{1)}$ Pusat Penelitian Arkeologi Nasional \\ Jl. Raya Condet Pejaten No.4 Jakarta Selatan. \\ E-mail: sarji_arkenas@yahoo.com \\ 2) Pusat Penelitian Arkeologi Nasional \\ Jl. Raya Condet Pejaten No.4 Jakarta Selatan. \\ E-mail:librainagurasi@yahoo.com \\ Naskah diterima 2 April 2018 - Revisi terakhir 11 Juni 2018 \\ Disetujui terbit 10 Juli 2018 - Tersedia secara online 1 Agustus 2018
}

\begin{abstract}
This paper highlights trading activities on the junction of the Kapuas River and Tayan River in Sanggau District, West Kalimantan. The meeting of two rivers is a strategic location, the river as a traffic lane for the growth of settlements and the rise of Malay kingdom. The kingdoms of West Kalimantan are generally located around river encounters, such as Sanggau, Tayan, Landak, Meliau, and Sintang. This paper aims to illustrate trade at the junction of the Kapuas and Tayan Rivers, for example part of the upstream-downstream trading system between the inland and river delta or coastal waters that rely on streams in the nineteenth century. The problem to be solved is how to conduct trade around river basin especially around meeting area of Kapuas River and Tayan River in the 19th century. The method used was descriptive, analytical, and historical. This research successfully revealed the landscape of trading activities, types of commodities, and trading system.
\end{abstract}

Keywords: The Junction of Kapuas and the Tayan River, Tayan Kingdom, Tayan Island, upstream - downstream, local and outside Borneo commodity

\footnotetext{
Abstrak

Tulisan ini menyoroti aktivitas perdagangan di pertemuan Sungai Kapuas dan Sungai Tayan, Kabupaten Sanggau, Kalimantan Barat. Pertemuan dua sungai merupakan lokasi yang strategis, sungai sebagai jalur lalu lintas, tempat tumbuhnya permukiman dan Kerajaan Melayu. Kerajaan-kerajaan di Kalimantan Barat secara umum terletak di sekitar pertemuan sungai, seperti Kerajaan Sanggau, Tayan, Landak, Meliau, dan Sintang. Tulisan ini bertujuan menggambarkan perdagangan di pertemuan Sungai
} 
Kapuas dan Tayan, sebagai salah satu contoh sistem perdagangan hulu-hilir antara bagian pedalaman dengan muara sungai atau pesisir yang bertumpu pada aliran sungai pada abad ke-19. Permasalahan yang hendak dipecahkan ialah faktor-faktor apa saja yang berpengaruh terhadap sistem perdagangan di pertemuan Sungai Kapuas dan Tayan abad ke-19. Metode yang digunakan ialah deskriptif, analitis, dan historis. Melalui penelitian ini berhasil diungkap lanskap aktivitas perdagangan, jenis-jenis komoditas, dan sistem perdagangannya.

Kata kunci: Pertemuan Sungai Kapuas dan Tayan, Kerajaan Tayan, Pulau Tayan, huluhilir, komoditas asli, dan luar Kalimantan

\section{PENDAHULUAN}

Pulau Kalimantan merupakan pulau terbesar kedua di Indonesia setelah Papua. Wilayahnya dialiri sungai-sungai besar, misalnya Sungai Kapuas, Barito, dan Mahakam. Sungai-sungai besar alirannya bercabang sehingga membentuk anakanak sungai, contohnya Sungai Tayan, merupakan anak sungai atau cabang dari aliran Sungai Kapuas. Keberadaan sungai di Kalimantan bagi kehidupan begitu penting, sebagai prasarana transportasi penghubung menuju daerah-daerah pedalaman. Selain sebagai prasarana transportasi, sungai juga berfungsi sebagai tempat hunian. Penduduk Kalimantan umumnya tinggal di sepanjang tepian sungai (Djubiantono, 1995:37). Pada mulanya, tumbuh hunian, selanjutnya diikuti dengan aktivitas pertukaran barang atau perdagangan dan tumbuhnya kerajaan di sepanjang sungai.

Kalimantan Barat memiliki potensi tinggalan budaya dari masa kerajaankerajaan. Penelitian di Kalimantan Barat pada ruang lingkup arkeologi telah dilakukan sejak tahun 1977 dan berlanjut, yang terkini pada tahun 2016. Pusat Penelitian Purbakala dan Peninggalan Nasional (PPPPN) melakukan survei dan menghimpun data-data kepurbakalaan yang meliputi keraton, makam, tembikar di Kabupaten Sanggau, Sintang, Pontianak, dan Kabupaten Ketapang, Kalimantan Barat pada tahun 1977 (Nitihaminoto, Armaeny, \& S.A, 1977:8--21). Penelitian lain di Kabupaten Ketapang telah mengungkap terdapatnya hubungan antara Tanjungpura di Kalimantan dengan Majapahit di Jawa. Data arkeologi berupa bentuk-bentuk nisan di Kompleks Makan Keramat Tujuh, Kompleks Keramat Sembilan di Ketapang, Kalimantan Barat, memiliki kemiripan dengan bentuk nisan di Troloyo, Trowulan, dan inskripsi aksara Arab dan Jawa Kuno. Berdasarkan tinggalan arkeologi di Ketapang tersebut, diduga telah terdapat hubungan perdagangan antara Tanjungpura dengan Majapahit pada abad ke-14 (Montana \& Surachman, 1995:72-80; Eriawati, Yondri, \& Vita, 2012:97-104). Nisan-nisan di Ketapang yang memiliki kemiripan dengan nisan di Troloyo diduga merupakan barang perdagangan yang didatangakan dari Majapahit ke Kalimantan Barat. Penelitian yang menyoroti aspek perdagangan dilakukan di Ketapang tahun 2015. Kerajaan Tanjungpura dan Matan merupakan penghasil beberapa komoditas, misalnya sagu, cendana, kapulaga, dan hasil tambang telah turut mendukung keberadaan kerajan-kerajaan 
di Kalimantan Barat (Penelitian, 2015:6869).

Penelitian lainnya di Kalimantan Barat ialah tentang kesejarahan yang menyoroti keberadaan para bangsawan tradisional kerajaan-kerajaan Melayu, etnis Cina, dan perekonomian di Kalimantan Barat pada abad ke-19. Penguasa tradisional telah memonopoli sistem perdagangan huluhilir di Kalimantan Barat pada abad ke19 (Winardi, 2012:31-35). Perdagangan hulu-hilir di Kalimantan Barat sangat dimungkinkan karena terdapatnya sungaisungai besar, terutama Sungai Kapuas dengan hulu di pedalaman Kalimantan di Putussibau, Kabupaten Kapuas Hulu adapun bagian hilir berada di pesisir bagian barat Kalimantan (Betha, Widodo, Mulyoutami, Nugroho, \& Noordwijk, 2008:1).

Tulisan ini membahas fenomena perdagangan di pertemuan Sungai Kapuas dan Sungai Tayan pada abad ke-19. Lokasi pertemuan dua sungai tersebut berada di Kecamatan Tayan Hilir, Kabupaten Sanggau. Pada kurun waktu abad ke19, di sekitar pertemuan Sungai Kapuas dan Tayan telah tumbuh Kerajaan Tayan dan permukiman orang Cina. Aktivitas perdagangan pada pertemuan Sungai Kapuas dan Sungai Tayan ini menarik dan penting untuk diungkap, terutama untuk memperdalam penelitian-penelitian di Kalimantan Barat yang sudah dilakukan sebelumnya. Kerajaan-kerajaan di Kalimantan Barat dan aspek ekonomi perdagangan banyak dibahas tetapi penelitian di pertemuan Sungai Kapuas dan Tayan Tayan di Sanggau belum diungkap.

Permasalahan dalam tulisan ini terkait dengan aktivitas perdagangan di lingkungan sekitar pertemuan sungai, permasalahan dirumuskan sebagai berikut: faktor-faktor apa saja yang berpengaruh terhadap sistem perdagangan di pertemuan Sungai Kapuas dan Tayan? Tulisan ini bertujuan mengungkap sistem pertukaran, jual beli komoditas perdagangan sebagai salah satu aspek perekonomian yang berlangsung di sekitar pertemuan Sungai Kapuas dan Tayan.

Studi ini termasuk ke dalam kajian arkeologi sejarah, suatu studi tentang kehidupan manusia masa lalu melalui tinggalan budaya materi dan memiliki ciri khas telah tersedianya sumber-sumber tertulis. Untuk menjawab permasalahan sistem pertukaran komoditas perdagangan di tepi sungai di Sanggau pada abad ke-19, maka dilakukan tahap survei arkeologi, survei lingkungan, dan penelusuran sumber tertulis. Survei arkeologi untuk memperoleh variabilitas tinggalan arkeologi sebagai data pokok. Survei lingkungan diperlukan untuk memperoleh gambaran tentang landsekap yang mendukung aktivitas perdagangan. Survei data tertulis merupakan suatu tahap penelusuran dokumen yang berisi informasi tentang riwayat Kerajaan Tayan, kehadiran Belanda sekitar abad ke-19, dan juga peta-peta kuno yang terkait dengan lokasi penelitian. Selain survei arkeologi, dilakukan survei lingkungan dan sumber tertulis. Data arkeologi, lingkungan, dan data dalam sumber tertulis yang telah terkumpul dideskripsi, lalu dianalisis. Antara data yang satu dengan lainnya diinterpretasikan untuk menggambarkan sistem perdagangan di pertemuan Sungai Kapuas dan Tayan. 


\section{HASIL DAN PEMBAHASAN}

Kerajaan Tayan dan Keberadaannya di antara Kerajaan Lain di Tepi Sungai Kapuas

Seperti diketahui, di Kalimantan Barat dulu tumbuh kerajaan-kerajaan Melayu, antara lain Kerajaan Pontianak, Sambas, Tanjungpura, Mempawah, Landak, Sintang, Tayan, Sanggau, dan Meliu. Orang-orang Melayu di Kalimantan Barat dapat dibagi menjadi dua besar komunitas, yakni masyarakat pesisir dan pedalaman. Komunitas Melayu pesisir terdiri atas Sambas, Mempawah, Landak, Pontianak, Sukadana, dan Matan/Ketapang; sedangkan Melayu pedalaman terdiri atas Sanggau, Sekadau, Sintang, Melawi, dan Kapuas Hulu/Ulu Kapuas (Ahyat, 2014:278).

Lokasi pusat kerajaan-kerajaan Melayu pada umumnya berada di tepi sungai, muara sungai, misalnya Sungai Sambas, Sungai Mempawah, dan Sungai Kapuas, bahkan ada pula yang terletak di pertemuan dua sungai. Wilayah Kerajaan Tayan dikelilingi oleh Kerajaan Pontianak dan Landak di sebelah barat, Meliau di sebelah selatan, Sanggau di sebelah utara, dan Sekadau di sebelah timur (lihat Lampiran 1: Peta 1). Pontianak merupakan kerajaan terbesar di antara kerajaan lainnya di Kalimantan Barat. Kerajaan Pontianak memiliki wilayah kerajaan-kerajaan kecil, di antaranya ialah Kerajaan Tayan. Pusat Kerajaan Tayan berada di tepi pertemuan Sungai Kapuas dan Sungai Tayan. Situs Kerajaan Tayan secara administratif berada di wilayah Desa Pedalaman, Kecamatan Tayan Hilir, Kabupaten Sanggau, Provinsi
Kalimantan Barat. Tayan pada masa sekarang merupakan ibu kota Kecamatan Tayan Hilir (Penelitian, 2016:22).

Awal perkembangan Kerajaan Tayan sulit ditelusuri mengingat beberapa kendala, seperti sedikitnya sumber tertulis. Beberapahalyang diketahui tentang sejarah Kerajaan Tayan adalah sebagai berikut. Kerajaan Tayan didirikan oleh Gusti Lekar, anak kedua dari Panembahan Dikiri (Raja Matan). Kedatangan Gusti Lekar di Tayan semula untuk mengamankan upeti dari rakyat daerah itu kepada Kerajaan Matan. Sebelumnya, pembawa upeti selalu mendapat gangguan oleh seseorang yang mengatakan dirinya raja di Kuala Lebai. Gusti Lekar bersama seseorang dari Suku Dayak yang bernama Kia Jaga dari Tebang berhasil mengamankan upeti tersebut sampai ke Kerajaan Matan. Berdirinya Kerajaan Tayan tersebut diduga sekitar awal abad ke-15. Gusti Lekar wafat dan dimakamkan pada sebuah bukit Meliau, tempat atau bukit tersebut masih termasuk wilayah Kerajaan Tayan. Pusat Kerajaan Tayan berada di suatu tempat yang bernama Rayang, terletak di bagian hulu Sungai Tayan (anonim, 2013:1). Ibu kota tempat kedudukan Raja Tayan di Rayang, kemudian dipindahkan di pertemuan Sungai Kapuas dan Sungai Tayan, tepatnya sebelah utara Sungai Kapuas dan sebelah timur Sungai Tayan dan didirikanlah istana atau keraton. Lokasi pusat kerjaan yang kedua tersebut pada masa sekarang termasuk wilayah Desa Pedalaman, Kecamatan Tayan Hilir, Kabupaten Sanggau (Penelitian, 2016:14 15). Panembahan adalah gelar pemimpin Kerajaan Tayan.

Kerajaan Tayan masa Hindia Belanda 
pada abad ke-19 merupakan bagian dari Afdeeling Pontianak, diperintah oleh seorang Panembahan. Terhadap Pemerintah Belanda, Tayan memberi pengakuan sebagai kekuasaan tertinggi yang sah (A. Republik Indonesia, 1971:LXXXVIII, XCVI, XCVIII). Perjalanan antara Kerajaan Tayan menuju Pontianak, ditempuh selama empat hari. Perjalanan melalui transportasi sungai dilakukan dengan menggunakan perahu ke arah hilir Sungai Kapuas. Kerajaan Tayan terletak tidak jauh dari Sungai Tayan yang bermuara di Sungai Kapuas. Posisi Tayan merupakan penghubung dengan daerah lainnya, seperti Sanggau di sebelah utara dan dapat menuju ke Serawak, Malaysia, dan Sekadau di sebelah timur. Tayan digambarkan sebagai negeri yang anggun (indah). Beberapa orang Belanda dan Kapitan Cina tinggal di wilayah ini. Wilayahnya merupakan daerah yang subur dengan air melimpah. Secara terperinci populasi penduduknya pada akhir abad ke-19 sekitar 4.200 jiwa, termasuk 3.900 orang Dayak, 300 orang Melayu, Bugis, dan beberapa orang Cina. Kerajaan Tayan memiliki beberapa daerah penting sebagai berikut. Rayang, merupakan suatu daerah berada di arah hulu Sungai Tayan, adalah tempat biasa yang dikunjungi oleh Panembahan Kerajaan Tayan. Di Rayang terdapat belasan rumah, ladang, dan kebun yang terawat dengan baik. Bakat, merupakan suatu daerah yang berada tidak jauh di timur laut Kerajaan Tayan, merupakan kampung utama, hampir secara khusus dihuni oleh orang Dayak. Meliau, merupakan suatu tempat yang terletak di sisi selatan Kapuas, sebelumnya merupakan sebuah pemerintahan dengan penguasa seorang panembahan sendiri, yang tinggal di ibu kota Meliau selama beberapa tahun. Selanjutnya, Meliau digabungkan dengan Tayan (Van Eck, 1898).

\section{Situs Kompleks Pemakaman Kemilun}

Lokasi administratif berada di Dusun Kemilun, Desa Kawat, Kecamatan Tayan Hilir, Kabupaten Sanggau. Situs Kemilun berada di bukit di tepi sungai, tepatnya terletak di bukit Kemilun, sebelah barat Sungai Tayan. Sungai Tayan terhubung dengan Sungai Kapuas karena bagian hilir atau muara dari Sungai Tayan berada di Sungai Kapuas. Situs tersebut merupakan kompleks pemakaman (pusara) raja-raja Tayan dan keluarganya. Bukit Kemilun, menurut informasi warga sekitar situs, dulu pernah menjadi pusat Kerajan Tayan, setelah pindah dari bukit Rayang di bagian hulu Sungai Tayan. Situasi situs banyak ditumbuhi tanaman karet yang kurang terawat. Tinggalan arkeologi di Situs Kemilun di antaranya adalah makam, fragmen keramik dan tembikar, peluru, serta damar.

Makam-makam di Situs Kemilun dibuat dari bahan batu dan kayu, beberapa di antaranya ada yang bercungkup. Batu dan kayu digunakan sebagai nisan dan jirat makam. Makam dengan nisan batu merupakan nisan polos tanpa jirat, tanpa ragam hias, dan tidak bercungkup. Makam dengan nisan dan jirat dari kayu pada umumnya dibuat kayu ulin yang diukir dan berinskripsi aksara Arab. Salah satu makam dengan nisan dan jirat dari bahan kayu merupakan makam dari tahun $1243 \mathrm{H}$ atau $1823 \mathrm{M}$, abad ke-19. Orientasi nisan adalah arah utara-selatan, memiliki dua nisan, denah empat persegi panjang, pipih, bagian atas hingga puncak 
mengecil, runcing, diberi ragam hias pahatan motif sulur-suluran, dan tumpal segi tiga. Jirat berdenah empat persegi panjang,

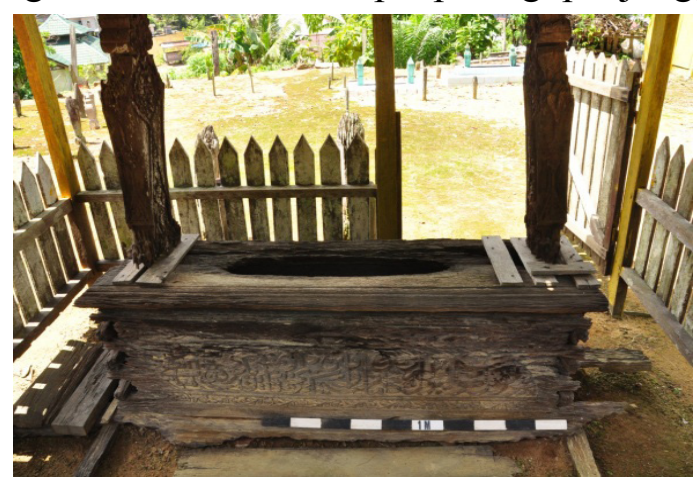

Gambar 1. Nisan dan jirat dari kayu berukir abad ke19 di Situs Kemilun (Sumber: Dokumen Puslitarkenas, 2016)

terdapat ragam hias inskripsi aksara Arab pada dinding kayu jirat (Gambar 1).

Kompleks pemakaman raja-raja Tayan merefleksikan keberadaan Kerajaan Tayan. Nisan dan jirat pada umumnya menggunakan bahan kayu hitam (kayu ulin). Penggunaan kayu hitam sebagai bahan baku nisan dan jirat merupakan simbol kemakmuran Kerajaan Tayan. Ragam hias yang terpahat pada nisan dan jirat merupakan simbol tingkat pengetahuan kesenian kerajaan. Kayu hitam merupakan barang perdagangan meskipun pihak keluarga kerajaan tidak akan membeli untuk memenuhi kebutuhannya, tetapi bagi pihak luar Kerajaan Tayan, kayu hitam tersebut memiliki nilai jual tinggi.

\section{Situs Keraton Tayan}

Lokasi administratifnya berada di Desa Pedalaman, Kecamatan Tayan Hilir, Kabupaten Sanggau. Nama lengkapnya adalah Keraton Pakunegara Tayan. Keraton ini merupakan lokasi keraton yang terakhir dari Kerajaan Tayan setelah berpindah dari bagian hulu dari Sungai Tayan. Lokasi di tepi Sungai Kapuas, berjarak 50 meter, orientasi menghadap ke Sungai Kapuas, ke arah selatan. Keraton Tayan diperkirakan dibangun dari tahun 1683-1718. Saat ini bangunan keraton tidak digunakan untuk rumah tinggal, tetapi bangunan kosong. Luas bangunan keraton 14,60 m $\mathrm{x}$ 40,50 m. Bangunan keraton berupa rumah panggung, dibuat dari bahan kayu, dua lantai, atap berbentuk limas yang ditutup dengan sirap. Bangunan keraton terdiri atas bangunan induk dan dapur, bangunan induk berdenah empat persegi panjang, memanjang dari arah depan lurus ke belakang. Adapun bangunan dapur berada di sebelah kiri atau sebelah timur, menyatu dengan bangunan induk. Pada bagian depan bangunan terdapat tangga naik untuk memasuki keraton (Gambar 2). Antara bangunan induk dengan dapur dihubungkan oleh pintu. Dua buah pucuk meriam dan dua buah guci keramik ditempatkan di sebelah kanan dan kiri singgasana raja.

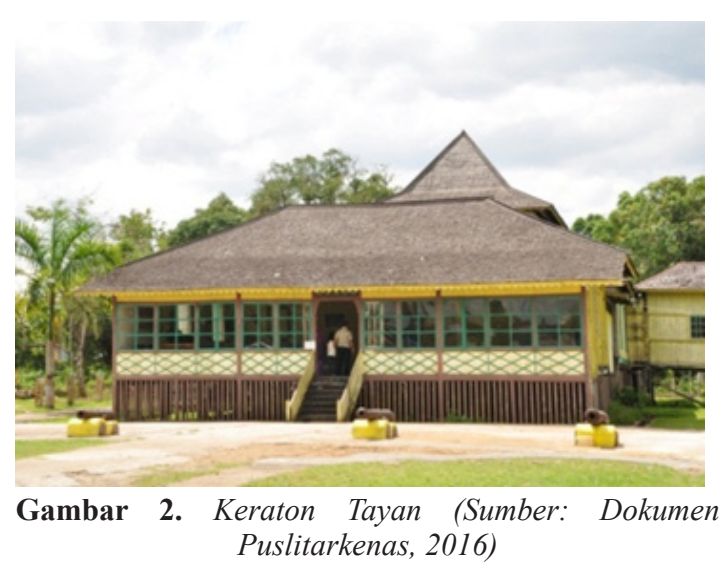

Sebuah ruang pada keraton adalah ruang untuk menyimpan benda-benda pusaka keraton. Jenis-jenis benda keraton terdiri atas benda-benda logam besi, benda-benda logam perunggu, benda-benda kaca, benda-benda kayu, keramik, dan stone ware. Benda-benda tersebut adalah tem- 
pat, hiasan dinding, nampan, senjata api, kuali logam, botol kaca berbentuk tabung, tameng (mandau), tombak, dan benda untuk permainan congklak, guci, dan tempayan.

Pada bagian depan keraton terdapat halaman yang luas untuk menempatkan delapan meriam yang disusun berjajar, ditata, berderet arah barat-timur. Beberapa meriam berinskripsi aksara Latin, yakni VOC. Pintu gerbang untuk memasuki halaman keraton terdapat di depan halaman, bersebelahan dengan pintu gerbang terdapat bekas tiang kapal Gusti

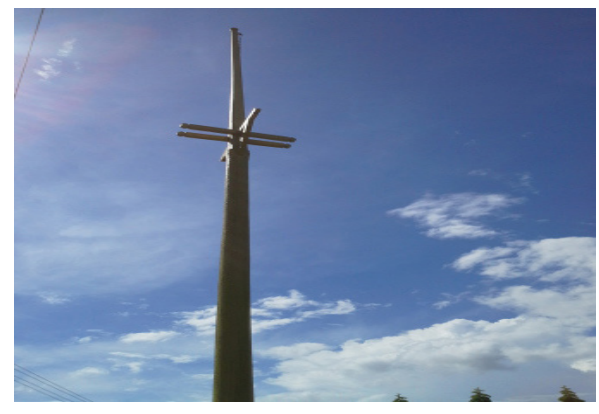

(a)

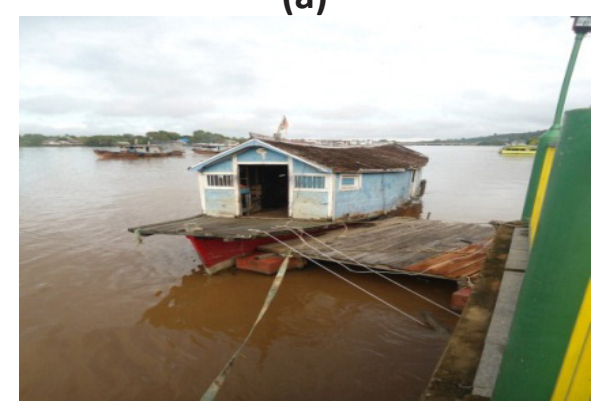

(b)

Gambar 3. (a) Bekas tiang Kapal Gusti Lekar; (b) Dermaga di depan Istana Tayan (Sumber: Dokumen Puslitarkenas, 2016)

Lekar. Keberadaannya menandakan keberadaan Keraton Tayan dan dimulainya peradaban Tayan di tepi Sungai Kapuas. Tepat di depan keraton di tepi Sungai Kapuas terdapat dermaga yang dibuat dari kayu ulin (besi), diduga dulu digunakan untuk merapatnya kapal atau perahu, termasuk mungkin untuk kapal-kapal keraton (Gambar 3) (Penelitian, 2016:2429).

\section{Situs Pulau Tayan}

Pulau Tayan merupakan satu pulau yang terletak di tengah-tengah Sungai Kapuas, luas pulau kurang lebih $2.000 \mathrm{~m}^{2}$, denah pulau memanjang arah timur-barat. Posisi pulau di muka pertemuan Sungai Kapuas dan Sungai Tayan. Sungai Kapuas mengalir ke arah barat-timur dan Sungai Tayan mengalir dari arah utara ke selatan. Pulau Tayan tersebut telah dipetakan oleh Belanda pada tahun 1887 (lihat Lampiran 1: Peta 2). Pulau Tayan dengan Keraton Tayan berhadapan, dipisahkan oleh Sungai Kapuas. Keraton Tayan menghadap ke selatan, menghadap ke arah Sungai Kapuas dan Pulau Tayan, keraton Tayan terlihat dari arah Pulau Tayan. Pulau Tayan merupakan suatu permukiman terutama dihuni oleh orang Cina. Secara administratif pulau ini termasuk Kelurahan Pulau Tayan, Kecamatan, Tayan Hilir, Kabupaten Sanggau. Permukiman penduduk terkonsentrasi pada bagian timur yang menghadap ke arah pertemuan Sungai Kapuas dan Sungai Tayan atau menghadap ke arah utara. Tercatat tahun 1828 atau abad ke-19 Pulau Tayan diserahakan oleh Kerajaan (negeri) Tayan kepada Pemerintah Belanda dan menjadi tempat kedudukan gezaghebber (pejabat setingkat letnan) (A. N. Republik Indonesia, 1973:LXXXVIII).

Berdasarkan peta lama Belanda tahun 1887 (lihat Lampiran 1: Peta 2) ditunjukkan bagian-bagian dari permukiman di $\mathrm{Pu}-$ lau Tayan yang diurutkan dari ujung timur ke arah barat sebagai berikut: (1) kedia- 
man pengawas Belanda (controleur), (2) gudang garam (zoutpakhuis), (3) kediaman Kapitan Cina (woning van den $\mathrm{Ka}$ pitein der Chineezen), (4) rumah-rumah petak orang Cina (chineeschie kampt), (5) kelenteng (chineesche temple), dan (6) chineesche graven (pemakaman Cina). Situasi lingkungan Pulau Tayan berupa dataran rendah berawa-rawa, ditumbuhi semak belukar dan alang-alang, dan terdapat pula tanaman bambu serta kelapa. Kediaman Panembahan (Raja Tayan), berdasarkan peta 1887 tersebut, tidak berada di tepi Sungai Kapuas, Desa Pedalaman, tetapi berada di Bukit Kemilun, sebelah utara Pulau Tayan, sebelah utara Sungai Kapuas.

Kondisi aktual pada tahun 2016, penduduk di Pulau Tayan mayoritas adalah etnis Cina. Mereka bermata pencaharian sebagai pedagang keperluan sehari-hari, misalnya sayur-mayur dan perabot rumah tangga, nelayan penangkap ikan di Sungai Kapuas, pengumpul hasil hutan (madu, rotan, gambir), pengumpul getah karet, dan peternak sapi, babi. Tinggalan budaya di Pulau Tayan yang masih dapat diamati pada tahun 2016, ada kesamaan pada peta lama 1887. Bekas gudang garam, deretan rumah orang-orang Cina, dan kelenteng, pada umumnya dibuat dari bahan kayu. Bekas gudang garam yang masih ada adalah bangunan yang dibuat dari kayu, tetapi tidak digunakan kembali. Kelenteng di Pulau Tayan berjumlah tiga berada di bagian tengah, timur, dan di ujung barat pulau. Kelenteng yang tertua ialah kelenteng yang berada di bagian tengah, posisi menghadap ke arah pertemuan Sungai Kapuas dan Sungai Tayan, kelenteng tersebut ditunjukkan pada peta 1887 (lihat Lampiran 1: Peta 2). Ketiga kelenteng tetap digunakan sebagai tempat ibadah orang-orang Cina.

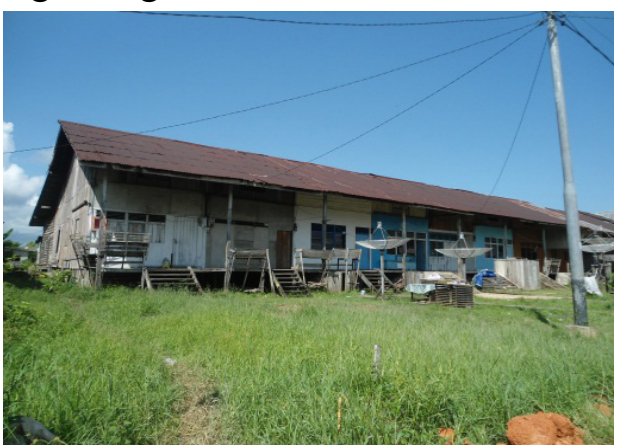

(a)

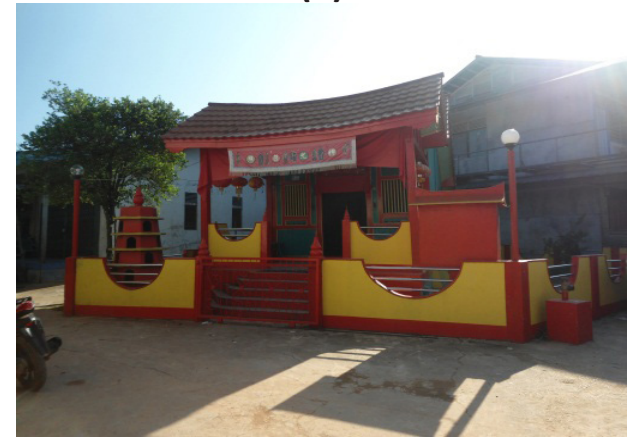

(b)

Gambar 4. (a) Rumah orang cina di Pulau Tayan; (b) Kelenteng tertua di Pulau Tayan (Sumber: Dokumen Puslitarkenas, 2016)

Potensi Geologi dan Botani Sekitar Aliran Sungai Kapuas

Sekitar aliran Sungai Kapuas memiliki potensi geologi dan botani, potensi tersebut merupakan sumber barang-barang niaga, komoditas lokal dari Kalimantan Barat. Barang-barang niaga tersebut, misalnya emas, getah perca, jelutung, rotan, tengkawang, kayu, kelapa, lada, gambir, sagu, dan karet (Heidhues, 2008:149, 158, 161, 162). Emas secara historis merupakan komoditas penting yang pernah dikelola oleh kerajaan-kerajaan Melayu di Kalimantan Barat yang didirikan di dekat muaramuara sungai, misalnya Kerajaan Tayan, Kerajaan Sanggau, Kerajaan Sintang pada abad ke-18 hingga akhir abad ke-19. Daerah-daerah penghasil emas terdapat 
di bagian selatan Sungai Kapuas, misalnya Simpang, Sukadana, Matan, dan Kandawangan. Daerah penghasil emas lainnya adalah sepanjang Sungai Tayan hingga ke Salimbau, antara Sanggau dan Sekadau, Sintang, Penei, dan muara sungai Silat dekat Salimbau. Emas dalam sejarahnya diusahakan orang Dayak, Cina, kemudian oleh bangsa Eropa (Posewitz, 1892).

Keberadaan emas di Kalimantan Barat telah diketahui sejak abad ke-8 pada masa Hindu oleh orang-orang Dayak di dalam gua di kaki Gunung Snaman, sekarang daerah Mandhor Kalimantan Barat (Posewitz, 1892:312). Emas pada umumnya didapatkan di pinggir atau di cekungan aliran Sungai Kapuas. Beberapa aliran sungai membawa pasir bercampur emas sehingga untuk mendapat serbuk atau bijih emas dilakukan dengan mendulang. Selain dengan mendulang, emas juga didapat dengan cara ditambang. Emas merupakan salah satu barang niaga yang diperdagangkan oleh penduduk di daerah hulu, daerah tujuan pengiriman adalah Cina, Asia Selatan, Asia Tenggara dan penguasa lokal. Emas sepanjang Sungai Kapuas di sekitar Sanggau dan Tayan diduga sudah diusahakan oleh orang Cina sebelum akhir abad ke-18 (Heidhues, 2008:36, 37, 142).

Potensi botani dari Kalimantan Barat pada umumnya adalah hasil hutan, baik berupa getah, buah, dan kayu, dari tanaman hutan, dikumpulkan sebagai komoditas lokal produk Kalimantan Barat sehingga tanaman hutan merupakan tanaman niaga. Komoditas yang dikumpulkan dari tanaman niaga dihasilkan dari daerah bagian Hulu anak-anak sungai. Keanekaragaman hasil hutan, di antaranya adalah getah perca, jelutung, rotan, tengkawang, kayu, kelapa, lada, gambir, sagu, dan karet.
Getah perca, sejenis produk karet-karetan yang dihasilkan oleh pohon tertentu (Palaquium dan Payena), umumnya digunakan sebagai bahan perekat, misalnya menambal sampan atau perahu yang bocor. Jelutung, seperti karet, elastis, hasil dari pohon tertentu, diekspor ke singapura. Produk jenis getah-getah tersebut umumnya dikumpulkan oleh orang Dayak. Rotan, digunakan sebagai bahan untuk membuat peralatan sehari-hari, misalnya untuk keranjang dan tali tambang untuk mengikat tiang rumah. Tengkawang atau illipe nut atau kacang illipe dihasilkan oleh pohon dipterocarp (L shorea spp). Tengkawang digunakan untuk bahan makanan sebagai lemak sayur, mengandung minyak yang juga dapat dibakar dan mengeluarkan api, seperti lilin. Kayu digunakan untuk kebutuhan mendirikan rumah atau sampan. Selain untuk kepentingan lokal, kayu juga diekspor. Kelapa dikeringkan menjadi kopra dikembangkan oleh imigran lainnya, yakni orang-orang Bugis pada abad ke 17--18. Lada, jenis lada yang dihasilkan adalah lada putih, komoditas yang sudah lama dikenal di wilayah Kalimantan dan menguntungkan. Lada diusahakan oleh orang-orang Cina. Gambir, getah yang diperoleh dari daun dan ranting tanaman, kemudian dipadatkan digunakan untuk campuran menyirih dan sebagai bahan pewarna. Karet, getah yang dihasilkan tanaman karet, tetapi berbeda dengan jenis karet-karetan lainnya, karet tergolong komoditas yang baru dikenal kemudian. Tanaman karet mulai ditanam dan dikembangkan di Kalimantan pada awal abad ke-19 oleh Belanda (Peluso, 2008). Perkebunan karet yang diusahakan oleh Belanda di Kalimantan Barat antara lain yang terdapat di Sintang (lihat Lampiran 1: Peta 3). Komoditas yang diperoleh dari 
tanaman niaga di Kalimantan Barat masih banyak yang lainnya, tidak dapat dikemukakan seluruhnya. Jenis-jenis komoditas tersebut disajikan dalam Tabel 1 berikut.

Tabel 1 Komoditas Asli dari Kalimantan Barat (Sumber: (Cleary, 1996:305)

\begin{tabular}{|c|c|c|}
\hline PRODUK & KEGUNAAN & SKALA PERDAGANGAN \\
\hline Palem Nibong & Tiang bangunan & Lokal \\
\hline Palem Nipah & Atap bangunan & Lokal \\
\hline Rotan & $\begin{array}{l}\text { Keranjang, tikar, pengikat } \\
\text { tiang rumah }\end{array}$ & Lokal/Regional \\
\hline Bambu & Bangunan & Lokal/ Regional \\
\hline Kayu Gaharu & Parfum & Regional/International \\
\hline Buah Pinang & $\begin{array}{l}\text { Menginang (menyirih), } \\
\text { obat }\end{array}$ & Lokal \\
\hline $\begin{array}{l}\text { Biji Buah Tengkawang (Illipe } \\
\text { nut) }\end{array}$ & Minyak & Lokal/Regional \\
\hline Kamper & Minyak, parfum & $\begin{array}{l}\text { Lokal/Regional/Interna- } \\
\text { tional }\end{array}$ \\
\hline Sagu & Bahan makanan & Lokal/Regional \\
\hline Pohon-Kayu Jelutung & Karet hutan & Regional/International \\
\hline Getah Damar & Lem, perekat & Regional/International \\
\hline
\end{tabular}

Sistem Perdagangan Hulu-Hilir di Pertemuan Sungai Kapuas dan Tayan

Perdagangan merupakan fenomena yang terdapat di Kalimantan Barat pada abad ke-19, bertumpu pada jalur Sungai Kapuas dan anak-anak sungainya. Sungai merupakan urat nadi kehidupan masyarakat, tepi-tepi aliran sungai menjadi tempat yang nyaman untuk tempat tinggal di Kalimantan Barat. Aliran Sungai Kapuas memiliki anak-anak sungai yang bermuara di Sungai Kapuas, misalnya Sungai Tayan. Antara bagian pedalaman atau hulu dengan muara sungai terdapat saling ketergantungan ekonomi, kecukupan kebutuhan bagian hulu akan bergantung dengan bagian hilir dan sebaliknya. Orang-orang yang tinggal di bagian hulu umumnya bermata pencaharian mengumpulkan hasil hutan, peladang, bercocok tanam. Hasil-hasil hutan, selain 
membentuk sistem yang khas yang disebut upstream-downstream relation (hubungan antara hulu-hilir). Sebagian besar pelabuhan dari kerajaan-kerajaan yang terletak agak jauh dari bagian hulu atau pedalaman, yakni terletak di muara sungai, tetapi masih bisa mengendalikan lalu lintas perdagangan sungai dengan menjalankan kedaulatan menuju hulu. Kerajaan kecil

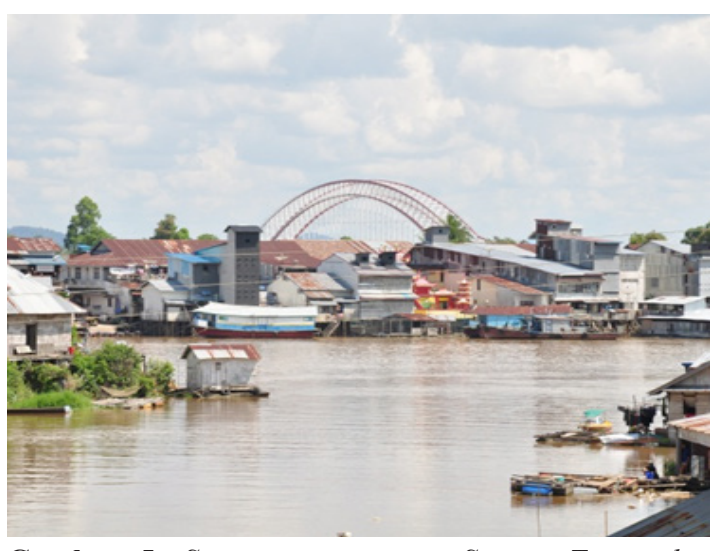

Gambar 5. Suasana pertemuan Sungai Tayan dan Sungai Kapuas, dengan latar belakang permukiman di Pulau Tayan, Kelenteng dan Jembatan Kapuas Tayan (Sumber: Dokumen Puslitarkenas, 2016)

di sepanjang tepi sungai lebih mendekati ke daerah hulu dan harus membayar upeti setiap tahun untuk menjamin keamanan politik ataupun pasokan produk impor. Penguasa yang berada di hilir menjamin tersediannya barang impor bagi penduduk pedalaman, seperti garam, besi, opium, dan tekstil yang tidak bisa langsung diakses langsung oleh orang pedalaman (Winardi, 2012).

Secara geografis, tata ruang aktivitas perdagangan berada di dataran rendah sekitar aliran dua sungai, yakni Sungai Kapuas dan Sungai Tayan. Sungai Kapuas termasuk kategori sungai besar di Kalimantan, memiliki percabangan atau anak sungai. Aliran sungai Kapuas mengalir dari bagian hulu ke hilir, dari arah barat ke timur, dan bercabang atau bertemu dengan Sungai Tayan yang mengalir arah utara-selatan. Sungai Tayan bermuara di Sungai Kapuas. Tepi Sungai Kapuas dan Tayan merupakan permukiman tepi sungai yang padat. Pertemuan dua sungai tersebut merupakan lokasi yang strategis, sebagai lalu lintas jalur perairan sungai, tempat tumbuhnya pemukiman, tempat berkembangnya kerajaan, dan berlangsungnya aktivitas perdagangan (Gambar 5). Agak menjorok ke bagian belakang sebelah timur dari Sungai Tayan terdapat bukit-bukit kecil.

Keraton Tayan dan Pulau Tayan berada pada muka pertemuan Sungai Kapuas dan Sungai Tayan. Pulau Tayan merupakan permukiman orang-orang Cina. Keraton Tayan berada di samping barat Sungai Tayan dan sebelah utara Sungai Tayan. Adapun Pulau Tayan tepat berada muara Sungai Tayan. Keraton Tayan sebagai pusat Kerajaan Tayan telah berpindah tiga kali, pola perpindahan pusat kerajaan adalah dari bagian pedalaman atau hulu Sungai Tayan menuju bagian hilir atau muara Sungai Tayan, di tepi Sungai Kapuas, mendekati Sungai yang besar, yakni Sungai Kapuas (lihat Lampiran 1: Peta 4). Pusat Kerajaan Tayan pada awalnya berada di Rayang, lokasi di bagian pedalaman atau hulu Sungai Tayan, dari Rayang kemudian berpindah ke Kemilun. Lokasi Kemilun sebelah selatan dari Rayang. Terakhir yang ketiga adalah keraton Tayan di tepi Sungai Kapuas, di bagian muara atau hilir Sungai Tayan (Penelitian, 2016:16-23).

Perpindahan pusat Kerajaan Tayan dari bagian hulu ke bagian hilir Sungai Tayan dipandang sebagai upaya untuk mendapatkan akses transporatsi Sungai 
Tayan dan Kapuas sebagai sungai yang lebih besar. Posisi yang berada di muara sungai dan tepi sungai yang besar memiliki sifat terbuka memberikan peluang ekonomi yang lebih luas dengan pihak luar. Peluang tersebut, misalnya, masuknya kapal-kapal yang berukuran lebih besar daripada sampan dan juga peluang transaksi yang lebih leluasa. Perlunya pihak Kerajaan Tayan turut dalam perdagangan yang bertumpu pada Sungai Kapuas ditunjukkan dengan adanya tinggalan budaya berupa dermaga di depan keraton tepi Sungai Kapuas, bekas tiang perahu yang tinggi, dan balok-balok kayu untuk dermaga (Penelitian, 2016:26).

Perpindahan pusat Kerajaan Tayan dari bagian hulu menuju ke bagiian hilir bersamaan dengan pertumbuhan Islam Melayu di Kalimantan Barat. Kehadiran dan terbentuknya pemukiman orang-orang Cina di Pulau Tayan yang setidak-tidaknya telah ada sebelum abad ke-18 dipandang juga sebagai faktor berpindahnya pusat Kerajaan Tayan mendekati daerah hilir (Heidhues, 2008:142). Imigran Cina awalnya berpusat di daerah pesisir pantai barat Kalimantan Barat, misalnya di Pontianak, berangsur - angsur mereka berpindah dari daerah pesisir Kalmantan Barat menuju ke pedalaman Sungai Kapuas, dari penambang emas menjadi pedagang.

Benda-benda budaya di Keraton Tayan disimpan sebagai benda pusaka yang masih dapat diamati pada masa sekarang umumnya adalah peralatan yang digunakan untuk keperluan sehari seharihari, alat permainan, dulang emas, senjata tradisional, dekorasi istana, meriam berbagai ukuran, bekas tiang sampan, dermaga. Peralatan dan alat tersebut dibuat dari logam besi, kaca, keramik, dan kayu. Peralatan untuk keperluan sehari-hari, misalnya nampan, tempat sirih, kuali, jambangan, guci, dan botol kaca. Dekorasi meliputi hiasan dinding yang dibuat dari besi, tempat lampu dinding dari besi, tanduk, dan gading. Alat mendulang emas dibuat dari kayu. Keperluan pertahanan (persenjataan) terdiri atas senjata sederhana tradisional, yakni tameng (mandau), tombak, sumpit yang dibuat dari bahan kayu dan bambu, teropong dari logam berinskripsi aksara Cina pada bagian unjungnya, dan meriam berbagai variasi. Meriam kecil merupakan pajangan di singgasana. Alat permainan berupa congklak dibuat dari bahan kayu (Lampiran 2). Kelenteng di Pulau Tayan merupakan bangunan ibadah yang dilengkapi dengan dekorasi bermacam warna dan tersedia pula dupa. Keperluan ibadah pada kelenteng yang dibuat dari kain, kertas bermacam warna pada masa lampau merupakan komoditas impor tidak diperoleh dari Tayan, tetapi didatangkan dari luar Tayan, misalnya Pontianak, atau bahkan diimpor dari Cina ((Heidhues, 2008:38). Benda-benda budaya koleksi Keraton Tayan yang dikategorikan sebagai komoditas dari luar (impor) disajikan pada Lampiran 2.

Garam merupakan kebutuhan seharihari untuk bahan makanan, keberadaannya bukan produk dari Tayan. Daerah penghasil garam di antaranya adalah Sukadana dan Brunei. Mengingat pentingnya garam, tetapi didatangkan dari daerah lain, garam menjadi komoditas dari luar Tayan yang diatur perdagangannya, misalnya tersedianya gudang. Gudang garam setidak-tidaknya telah ada di Pulau Tayan pada abad ke-19. Secara fisik tinggalan 
budaya berupa gudang garam pada masa sekarang tidak dijumpai di Pulau Tayan, tetapi diketahui dari data berupa peta kuno abad ke-19 yang menunjukkan terdapatnya gudang garam (zoutpakhuis) di Pulau Tayan. Garam barang impor penting, bahkan ada yang didatangkan dari Jawa. Perdagangan garam dimonopoli oleh Pemerintah Hindia Belanda (Heidhues, 2008:148). Terkait dengan hal tersebut di Pulau Tayan, selain gudang garam juga terdapat tempat tinggal controleur orang Belanda dan kapiten Cina (Kapitein der Chineeze). Keberadaan gudang garam, tempat tinggal controluer dan Kapitein der Chineeze secara tidak langsung berkaitan dengan perdagangan komoditas garam yang dimonopoli oleh pemerintah Hindia Belanda sebagai satu bentuk pengendalian perdagangan. Pemasokan garam dari luar Tayan melalui pemerintah Belanda.

Aktivitas perdagangan di pertemuan Sungai Kapuas dan Sungai Tayan merupakan satu contoh bagian kecil dari

\begin{tabular}{|l|l|l|}
\hline \multicolumn{1}{|c|}{ Produk } & \multicolumn{1}{c|}{ Kegunaan } & \multicolumn{1}{c|}{ Asal Impor } \\
\hline Sutera & Bahan pakaian & Cina \\
\hline Tembikar (keramik) & Peralatan sehari-hari & Cina \\
\hline Gula-gula & Bahan makanan & Cina \\
\hline Periuk besi & Peralatan sehari & Cina \\
\hline Keperluan keagamaan orang-orang Cina & Keperluan keagamaan & Cina \\
\hline Candu & Campuran tembakau diisap & Cina \\
\hline Garam & Bahan masakan & Jawa \\
\hline Beras & Bahan makanan & \\
\hline
\end{tabular}

(Sumber: (Heidhues, 2008, pp. 38, 41Dimodifikasi)

sistem perdagangan hulu-hilir yang lebih besar yakni jaringan perdagangan antara daerah pesisir barat Kalimantan dengan daerah hulu (pedalaman) di Kalimantan Barat. Daerah pesisiryang dimaksud adalah daerah sekitar muara Sungai Kapuas di pantai barat Kalimantan, yakni Pontianak.
Lokasi Tayan berada agak menjorok ke tengah dari muara sungai Kapuas, kedudukannya sebagai penghubung antara daerah pesisir barat Kalimantan (Pontianak dan sekitarnya) dengan daerah pedalaman (hulu) Kalimantan. Pontianak merupakan daerah yang berada di bagian muara Sungai Kapuas, dekat dan berhubungan dengan laut di pantai barat Kalimantan. Pelabuhan Pontianak sebagai pintu masuk penghubung pesisir barat Kalimantan Barat dengan daerah-daerah luar Kalimantan misalnya pantai timur Sumatra, Semenanjung Melayu, dan Cina. Komoditas impor yang didatangkan dari luar masuk ke Kalimantan Barat melalui pelabuhan Pontianak, selanjutnya menuju ke daerah pedalaman. Komoditas dari luar (impor) yang masuk melalui pelabuhan

Tabel 2 Komoditas dari Luar Kalimantan Barat melalui Pelabuhan Pontianak Pontianak disajikan pada Tabel 2 berikut. 
Lansekap berada di dataran rendah di muka pertemuan Sungai Tayan dan Kapuas yang berhadapan dengan Pulau Tayan. Lansekap di muka pertemuan sungai, muara sungai, memiliki sifat terbuka dengan dunia luar, menghubungkan antara bagian hulu dengan bagian hilir Sungai Tayan, dan terhubung pula dengan negeri-negeri lainnya di sepanjang Sungai Kapuas.

Perdagangan sepanjang aliran Sungai Kapuas dan anak-anak sungainya termasuk di Tayan, menggunakan sistem hulu-hilir. Daerah-daerah di pedalaman Sungai Tayan, muara Sungai Tayan, daerah lain di tepi aliran Sungai Kapuas, daerah pesisir Kalimantan Barat, semuanya terdapat saling interaksi dan saling ketergantungan.Terdapat dua kelompok komoditas (barang niaga), yakni pertama kelompok komoditas lokal dan kedua kelompok komoditas yang berasal dari luar Tayan dan atau dari luar Kalimantan Barat. Kelompok komoditas lokal terdiri atas hasil tambang emas dan hasil hutan. Emas merupakan hasil tambang andalan, adapun hasil hutan pada umumnya adalah getah, kayu, produk karet-karetan yang dikumpulkan dari tanaman hutan, serta rotan. Produk-produk dari luar yang menjadi bahan tukar yang penting misalnya keramik dan barang dari bahan logam. Garam merupakan barang niaga yang dimonopoli oleh Pemerintah Hindia Belanda.

Berlangsungnya sistem perdagangan hulu-hilir di pertemuan Sungai Kapuas dan Tayan sangat dimungkinkan karena terdapatnya beberapa faktor yang memengaruhi, seperti adanya sejumlah hasil bumi dari area hulu (getah, perca, tengkawang, dan lain-lain) yang dibutuhkan oleh daerah pesisir. Demikian juga sebaliknya, adanya barang perdagangan dari luar, seperti garam dan peralatan sehari-hari yang dibutuhkan daerah Tayan. Adanya akses penghubung berupa Sungai Kapuas dan Sungai Tayan. Adanya kawasan pertemuan kedua sungai dan Kerajaan Tayan yang menguasai dan mengatur perdagangan di kawasan tersebut. Adanya pelakupelaku perdagangan yang bermukim di Pulau Tayan, seperti orang Cina dan Belanda. Dalam sistem perdagangan hulu-hilir, daerah pesisir Kalimantan bagian barat tidak akan berarti tanpa adanya keberadaan daerah pedalaman, seperti Tayan. Kerajaan-kerajaan Melayu di sepanjang Sungai Kapuas, misalnya Tayan dan Sanggau tumbuh karena sistem perdagangan hulu-hilir yang maju.

\section{DAFTAR PUSTAKA}

Ahyat, I. S. (2014). The Dynamic of Malay Culture in West Kalimantan in the 20th Century. Journal of Education and Learning, 8 (3), 273-280.

Anonim. (2013). Terjemahan Naskah Kolonial Belanda Abad XVIII, Tayan dalam Catatan Kolonial Abad XVIIItle. Sanggau: Keraton Tayan pakunegara.

Betha, L., Widodo, R., Mulyoutami, E., Nugroho, D. A., \& Noordwijk, M. Van. (2008). Kajian Kondisi Hidrologis DAS Kapuas Hulu, Kabupaten Kapuas Hulu, Kalimantan Barat. Retrieved February 17, 2018, from http://www.worldagroforestry. org/downloads/Publications/PDFS/WP15426.pdf 
Cleary, M. C. (1996). Indigenous Trade and European Economic Intervention in NorthWest Borneo c.1860--1930. Modern Asian Studies, 30, No. 2, 301-324.

Djubiantono, T. (1995). Stratigrafi Situs Serok, Kotamadya Pontianak, Kalimantan Barat. Jurnal Penelitian Balai Arkeologi Bandung, 2/November, 37-42.

Eriawati, Y., Yondri, L., \& Vita. (2012). Penelitian Arkeologi Masa Hindu Buddha di Wilayah Kabupaten Ketapang Provinsi Kalimantan Barat. Laporan penelitian Arkeologi. Jakarta.

Heidhues, M. S. (2008). Penambang Emas, Petani, dan Pedagang di "Distrik Tioghoa" Kalimantan Barat. Jakarta: Yayasan Nabil.

Keyser, De, F., \& Noya-Sinay, J. (1992). History of geoscientific investigations in West Kalimantan, Indonesia. BMR Journal of Australian Geology \& Geophysics, 13.

Montana, S., \& Surachman, H. (1995). Tinggalan Arkeologi Islam di Daerah Ketapang, Kalimantan Barat. Jurnal Penelitian Balai Arkeologi Bandung, 2, 72-87.

Nitihaminoto, G., Armaeny, \& S.A, K. (1977). Survai di daerah Kalimantan Barat, Berita Penelitian Arkeologi No.6. Jakarta.

Peluso, N. L. (2008). A Political Ecology of Violence and Territory in West Kalimantan. Retrieved June 13, 2018, from http://onlinelibrary.wiley.com/doi/10.1111/j.14678373.2008.00360.x/full

Penelitian, T. (2015). Kota-Kota Kerajaan di Kalimantan Barat: Pusat Produksi, Industri, dan Distribusi Perdagangan. Laporan Penelitian Arkeologi (LPA). Jakarta.

Penelitian, T. (2016). Kota-Kota Kerajaan di Kalimantan Barat: Pusat Produksi, Industri, dan Distribusi Perdagangan. Laporan Penelitian Arkeologi (LPA). Jakarta.

Posewitz, T. (1892). Borneo Its Geology and Mineral Resources. London: Edward Stanford.

Republik Indonesia, A. (1971). Laporan Politik Tahun 1837 (Staatkundig Overzicht van Nederlandsch Indie, 1837) Penerbitan Sumber-Sumber Sejarah No.4. Jakarta: Arsip Nasional Republik Indonesia (ANRI).

Republik Indonesia, A. N. (1973). Ikhtisar Keadaan Politik Hindia-Belanda Tahun 1839-1848, Penerbitan Sumber-Sumber Sejarah No.5. Jakarta: Arsip Nasional Republik Indonesia (ANRI).

Van Eck, R. (1898). Handleiding Bij Beoefening Der Land- En Volkenkunde Van Nederlandsch Oost-Indie. Breda: Ter Drukkerij van BROESE \& COMP. voor Rekening Van De KONINKLIJK MILITAIRE ACADEMIE.

Winardi, U. N. (2012). Ethnic Tension, Alliance and Clientelism: The Political Development of West Borneo, 1895-1950. Retrieved from https://openaccess.leidenuniv. nl/handle/1887/19785 


\section{Lampiran 1}

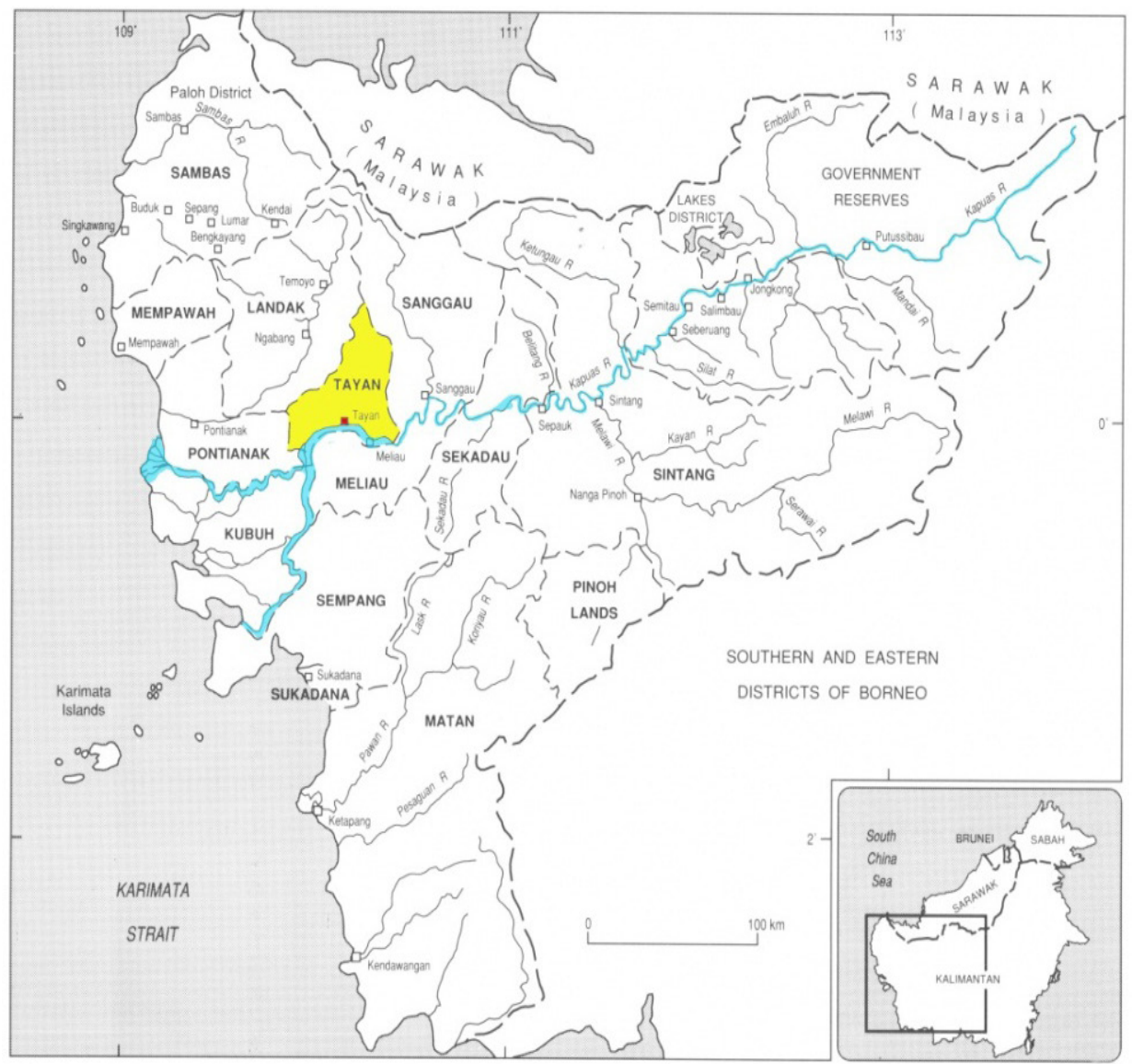

Peta 1. Posisi dan wilayah Kerajaan Tayan, di antara kerajaan lain di Kalimantan Barat periode sebelum Perang Dunia II (Sumber: Keyser, De, \& Noya-Sinay, 1992:253)

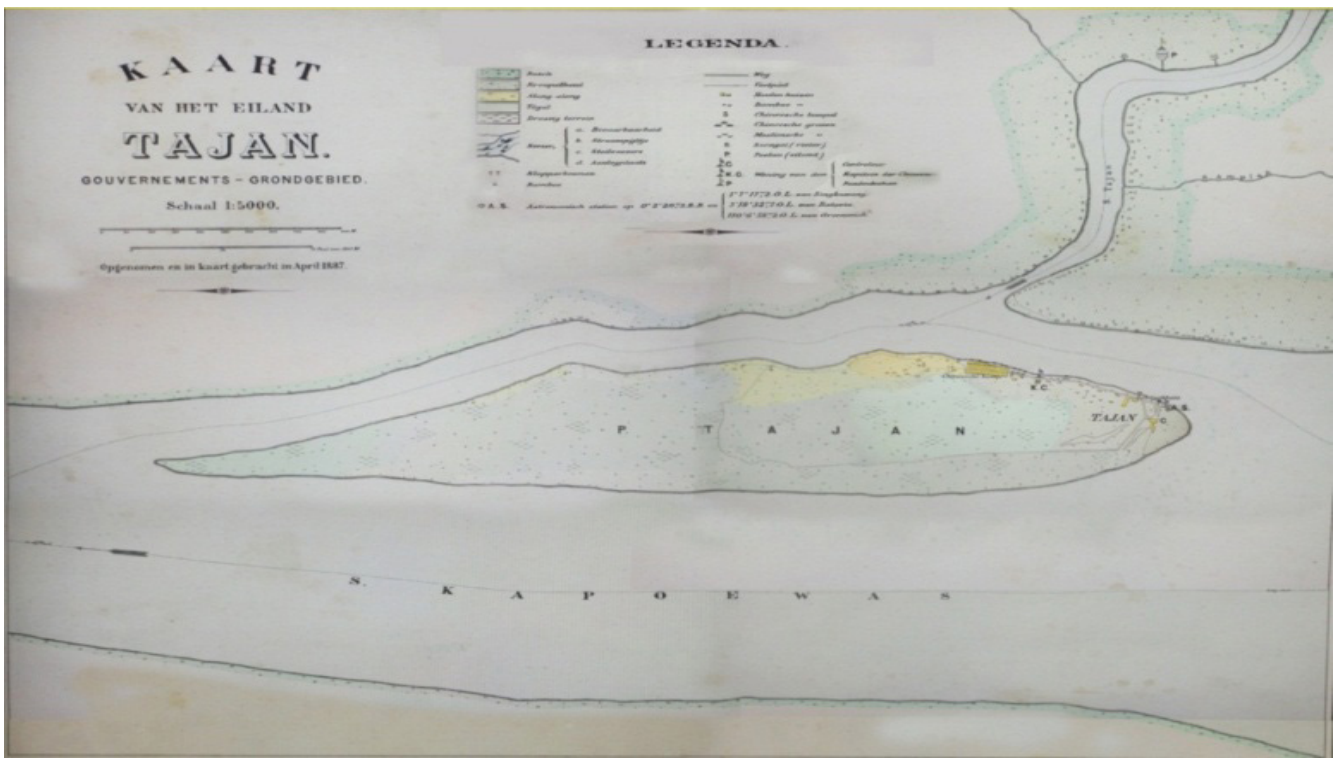

Peta 2. Peta keletakan Pulau dan Keraton Tayan tahun 1887 (Sumber: KITLV) 


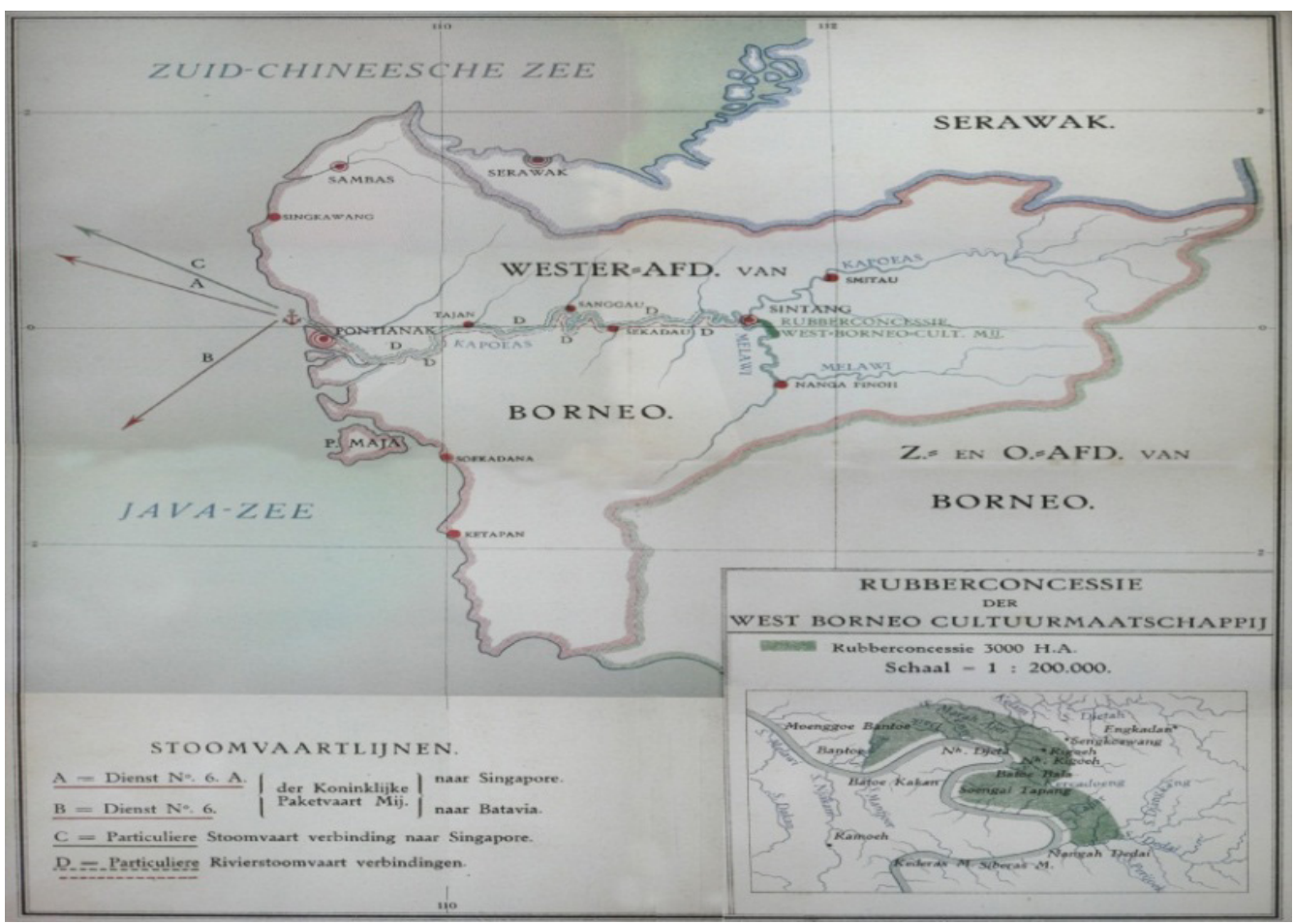

Peta 3. Lokasi penanaman karet di Sintang, Kaliman Barat tahun 1915 (Sumber: KITLV)

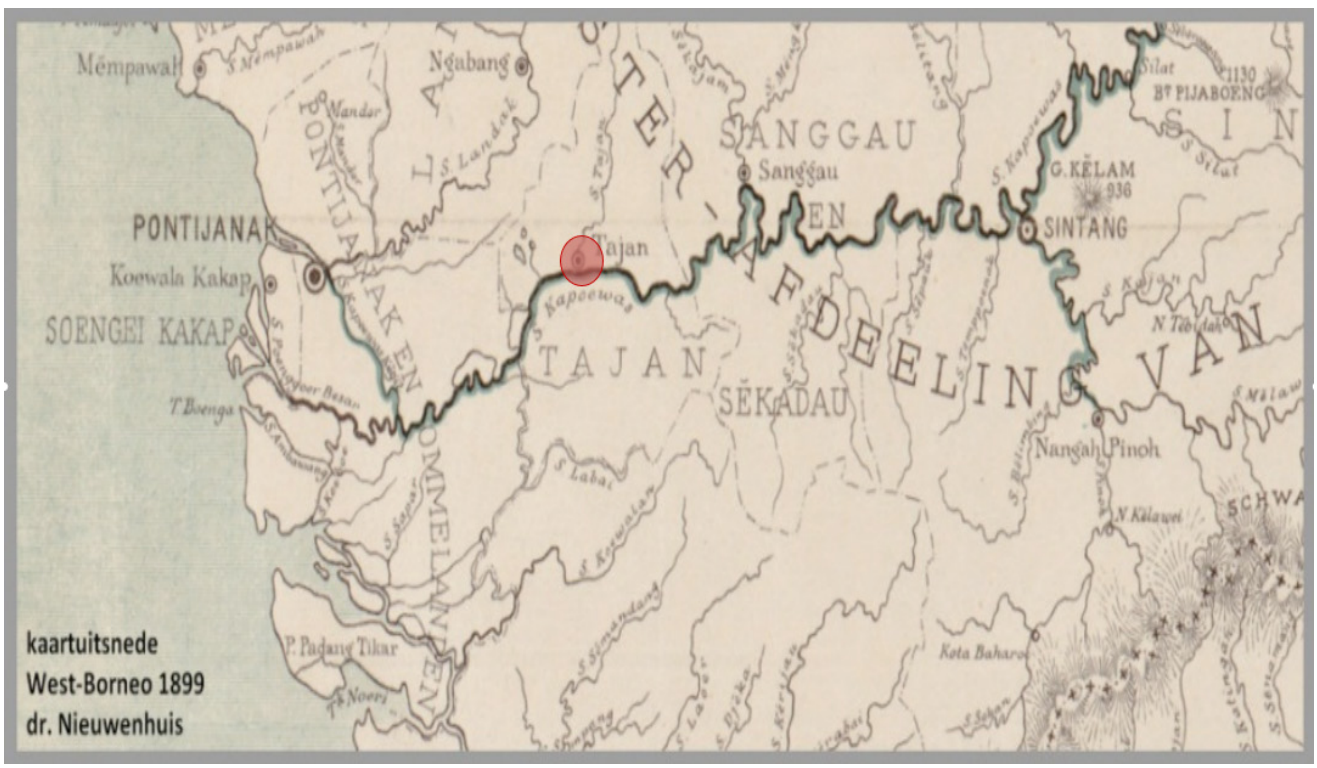

Peta 4. Keletakan Tayan di pertemuan Sungai Kapuas dan Sungai Tayan (Sumber: KITLV) 
PURBAWIDYa $\square$ Vol. 7, No. 1, Juni 2018:7 1-88

\section{Lampiran 2}

Tabel: Benda-Benda Budaya Koleksi

Keraton Tayan Kategori Komoditas Impor

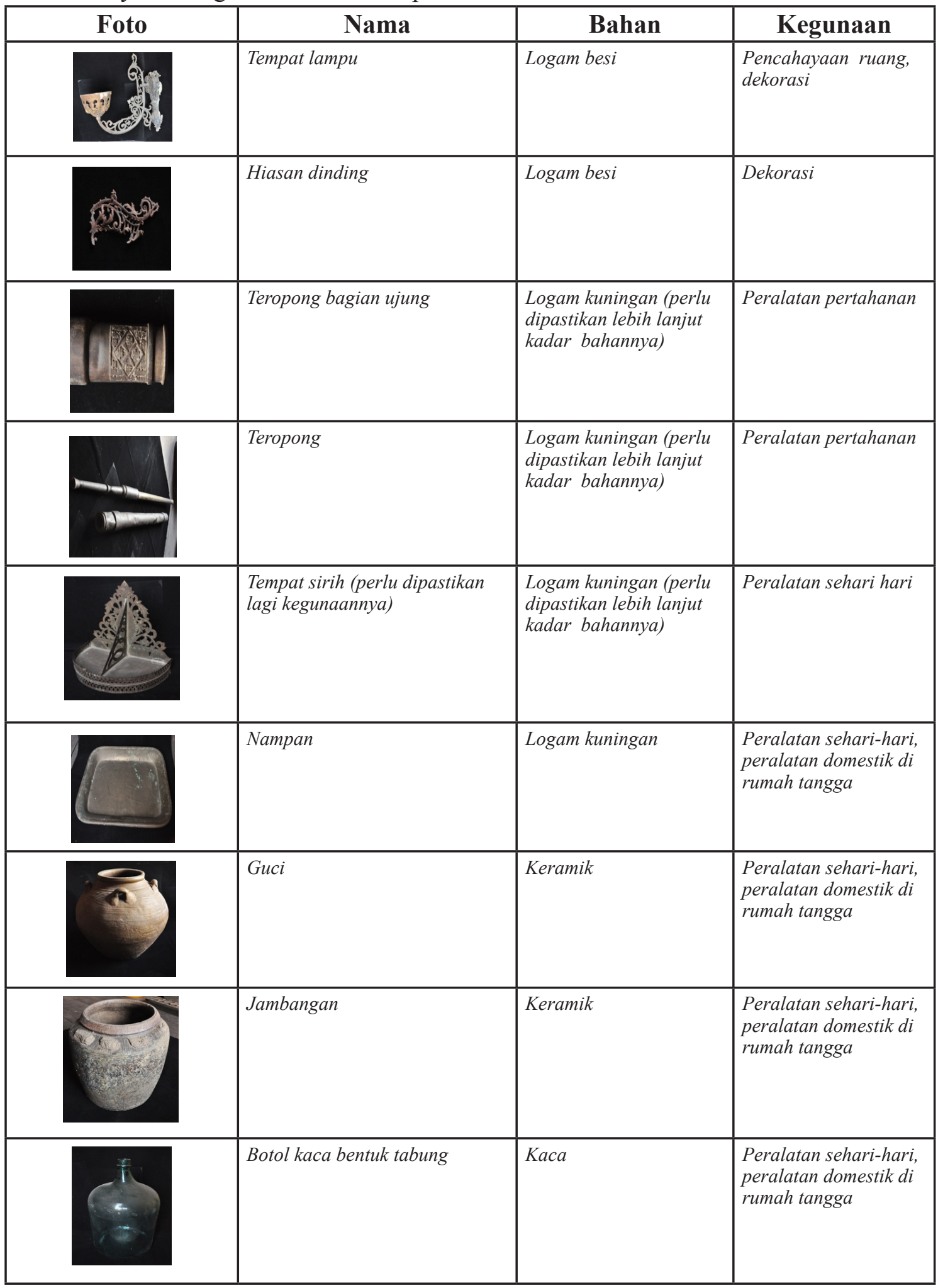

